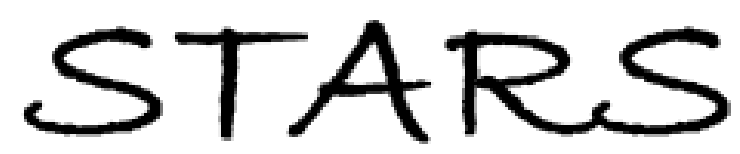

University of Central Florida

STARS

$11-6-2015$

\title{
Are Travel Purchases More Satisfactory Than Nontravel Experiential Purchases and Material Purchases? An Exploratory Study
}

Galia Fuchs

Po-Ju Chen

University of Central Florida, Po-Ju.Chen@ucf.edu

Abraham Pizam

University of Central Florida, Abraham.Pizam@ucf.edu

Part of the Hospitality Administration and Management Commons, and the Tourism and Travel Commons

Find similar works at: https://stars.library.ucf.edu/rosenscholar

University of Central Florida Libraries http://library.ucf.edu

This Paper is brought to you for free and open access by the Rosen College of Hospitality Management at STARS. It has been accepted for inclusion in Rosen Faculty Scholarship and Creative Works by an authorized administrator of STARS. For more information, please contact STARS@ucf.edu.

Original Citation

Fuchs, G., Chen, P. J. and Pizam, A. Are Travel Purchases More Satisfactory than Non-Travel Experiential Purchases and Material Purchases?: An Exploratory Study. Tourism Analysis, 20(5), p. 487-497.

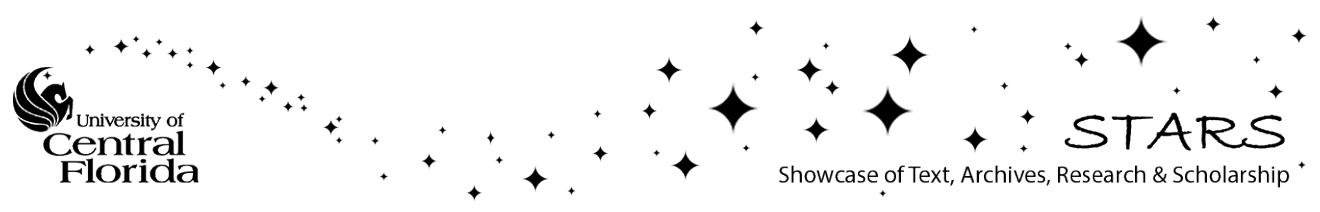




\title{
ARE TRAVEL PURCHASES MORE SATISFACTORY THAN NONTRAVEL EXPERIENTIAL PURCHASES AND MATERIAL PURCHASES? AN EXPLORATORY STUDY
}

\author{
GALIA FUCHS, * PO-JU CHEN, † AND ABRAHAM PIZAM $†$ \\ *Department of Hotel and Tourism Management, The Guilford Glazer Faculty of Business and Management, \\ Ben-Gurion University of the Negev, Beer-Sheva, Israel \\ †Rosen College of Hospitality Management, University of Central Florida, Orlando, FL, USA
}

\begin{abstract}
Satisfaction derived from purchases can affect one's happiness and quality of life. Previous studies illustrated that this effect is not equal across purchase categories. Specifically, experiential purchases were found to bring more satisfaction and happiness to consumers than material purchases. However, these comparison studies treated a variety of experiential purchases as one homogeneous category regardless of their nature of consumption. Therefore, the purpose of this study was to bridge this gap and to assess the difference in the level of satisfaction among the three purchase categories: material, travel (composite event experiential purchases), and nontravel experiential purchases (single event experiential purchases). Moreover, this study attempted to ascertain the consistency of these differences across several purchases of each category. By analyzing the satisfaction derived from past actual purchases of 282 participants it was found that respondents were more satisfied with past travel purchases than both past nontravel experiential purchases, and past material purchases. In addition, this study found differences between US and Israeli samples regarding purchase satisfaction derived from the three categories. Lastly, this study also discovered that the price paid for purchases in each of the three categories did not have an effect on the derived satisfaction.
\end{abstract}

Key words: Experiential purchases; Material purchases; Travel purchases;

Satisfaction with purchases

\section{Introduction}

It is commonly accepted that motivation to purchase products and services is driven by the desire to satisfy needs. It is further recognized that some of these purchases and the satisfaction derived from them can affect one's happiness as well as one's quality of life (Howell \& Hill, 2009; Neal, Uysal, \& Sirgy, 2007). Studies conducted on the influence of these purchases on consumers divided the purchases into two categories: material purchases and experiential purchases (Caprariello \& Reis, 2013; Carter

Address correspondence to Galia Fuchs, Ph.D., Department of Hotel and Tourism Management, The Guilford Glazer Faculty of Business and Management, Ben-Gurion University of the Negev, Beer-Sheva 84105, Israel. Tel: (972) 54-6275125; Fax: (972)-8-6472920; E-mail: galiaf@som.bgu.ac.il 
\& Gilovich, 2010, 2012; Dunn, Gilbert, \& Wilson, 2011; Howell \& Hill, 2009; Nicolao, Irawin, \& Goodman, 2009; Van Boven \& Gilovich, 2003). Previous studies also revealed that experiential purchases bring more satisfaction and happiness to consumers than material purchases (Caprariello \& Reis, 2013; Dunn et al., 2011; Howell \& Hill, 2009; Nicolao et al., 2009; Van Boven \& Gilovich, 2003).

However, these comparison studies treated a variety of experiential purchases as one category regardless of their nature of consumption. The experiential purchase can be a single event purchase (i.e., dinning in a restaurant or a spa treatment) or a series of events and activities of consumption that are incorporated into one experiential purchase (i.e., a vacation that is composed of a variety of experiential purchases). The consumption of experiential purchases can take place in familiar surroundings or while traveling (Dolnicar, Yanamandram, \& Cliff, 2012). Travel, considered to be an experiential purchase, involves a whole course of activities (pretrip, during trip, and posttrip) that result in the composite nature of satisfaction judgment and happiness (Kruger, 2012; Neal \& Gursoy, 2008). Thus, the purpose of this study was to bridge this gap and to assess the difference in the level of satisfaction among the three categories of purchases: material, composite event experiential purchases (travel), and single event experiential purchases (nontravel experiential purchases). Moreover, the study attempts to assess the consistency of these differences across several meaningful purchases of each category. Furthermore, this study seeks to determine if there are differences in purchase satisfaction between segments of travelers (i.e., nationality).

\section{Literature Review}

\section{What Distinguishes Material From Experiential Purchases?}

Nicolao et al. (2009) define material purchases (i.e., jewelry, cars) as tangible. That is, these articles may be taken from place to place, last beyond a couple of days, and take up physical space. They further define experiential purchases (i.e., vacations, spa treatments, restaurants) as intangiblelimiting the consumer to an event that is finite in time. As Carter and Gilovich (2012) concluded: "material possessions are part of the manufacturing economy; experiences are part of the service economy. One purchases an experience to do and a material possession to have” (p. 1305).

Material purchases persist in time and space, a fact that allows comparing and wishing for better and newer, whereas experiences persist in our memories (Carter \& Gilovich, 2010). Thus, experiences tend to be less exchangeable than material goods because they are "inside" rather than "outside” our being.

\section{Satisfaction Derived From Material and Experiential Purchases}

Previous findings indicate that experiential purchases tend to provide more enduring satisfaction than material purchases (Carter \& Gilovich, 2010, 2012; Howell \& Hill, 2009; Rosenzweig \& Gilovich, 2012; Van Boven \& Gilovich, 2003). According to Nicolao et al. (2009) these results are limited to positive purchases only. For negative purchases, experiences have no advantage over material goods regarding satisfaction and happiness. The possible explanations for the view that experiential purchases bring more satisfaction and happiness than material purchases are associated with the following factors: social context, the purchase decision process, and time.

Social Context. Unlike material purchases, experiential purchases tend to encourage social connections (Carter \& Gilovich, 2010). Companionship makes experiences more enjoyable and strengthens the bonds of friendship. Experiential purchases involve social interaction with other people (Nicolao et al., 2009) and are a major source of happiness (Argyle, 1999). In their study experiential purchases were more likely to be shared with others, whereas material purchases were more prone to solitary use, which may account for their differential effects on happiness and satisfaction (Caprariello \& Reis, 2013). Shared activities in comparison to solitary purchases are more likely to satisfy the need to belong (Howell \& Hill, 2009), which is a necessary ingredient for promoting well-being (Baumeister \& Leary, 1995; Ryan \& Deci, 2000). Experiential purchases tend to have more of a narrative structure than 
material purchases (Van Boven \& Gilovich, 2003). This characteristic increases the tendency to discuss experiences with others, which may in turn increase the enjoyment of positive experiences above and beyond the effect derived from the experience itself (Raghunathan \& Corfman, 2006; Reis et al., 2010). Regarding material purchases, those who make and then discuss them, may be stigmatized by others (Van Boven, Campbell, \& Gilovich, 2010).

Decision-Making Process. Another factor that could explain the difference in satisfaction derived from purchases is the decision-making process itself. The evaluation of experiences tends to be less comparative than that of material purchases. The tangible nature of possessions makes them easier to compare here and now, while experiential purchases are hard to compare retrospectively (Carter \& Gilovich, 2010). According to Carter and Gilovich (2010) experiential purchase decisions are easier to make and more likely result in wellbeing. Their conclusion about the lightness of the decisions-making process of experiential purchases compared to material purchases is not congruent with Zeithaml, Bitner, and Gremler (2009), who indicate that purchases high in "experience qualities" compared to purchases high in "search qualities" are more difficult to evaluate because they are purchased and consumed before assessment is possible (e.g., choosing a hotel or a restaurant). In comparison, material purchases, which belong to the category of "search qualities," allow the consumer to evaluate and determine the attributes of the product before the purchase. However, according to Carter and Gilovich (2012), the intangible, subjective nature of experiences enables finding various positive dimensions of evaluation, while the tangible and objective nature of material purchases does not enable positive reinterpretation.

Carter and Gilovich (2010) associated between type of purchase, satisfaction level induced by the purchase, and the decision-making strategy"maximizing” (selecting the best possible alternative after all possible options were compared) and "satisfying" (selecting the first option that meets the standard from a minimum standard for an overall quality that was set). They found that the likelihood of applying the maximizing strategy in the purchasing decision-making process is higher when the options are directly comparable (as with material purchases), whereas the utilization of the satisfying strategy is more likely to occur when the options are not directly comparable (as with experiential purchases). These authors suggested that the use of a maximization strategy is associated with negative psychological outcomes, whereas the use of the satisficing approach leads to a positive feeling - even if the purchase is not the ideal one. It should be noted that employing the satisficing strategy in the decision-making process does not necessarily promise satisfaction from the purchase. According to marketing literature, satisfaction is "the costumer's evaluation of a product or service in terms of whether that product or service has met the costumer's needs and expectations" (Zeithaml et al., 2009, p. 104). Thus, when discussing satisfaction, there is a need to relate it to the subject of expectations.

As the expectations from the purchases are a crucial component in determining the level of satisfaction, it is interesting to notice findings which indicate that the perceived number of alternatives affect the level of expectations: the higher the number of perceived alternatives, the higher the level of expectations (Zeithaml et al., 2009). These findings reinforce the conclusions of Carter and Gilovich (2010) regarding potential differences in satisfaction from material and experiential purchases, but for a different reason. According to Zeithaml et al. (2009) and in line with Carter and Gilovich (2010), it could be speculated that since experiential purchases compared to material purchases have fewer alternatives in the set of choices, the level of expectation from them might be lower than the level of expectation from material purchases and, therefore, the level of satisfaction might be higher. However, it should be noted that there are additional factors that set the expectation level and affect satisfaction. Those factors might be, for example, personal needs, situational factors, explicit promises, wordof-mouth communication, and past experience (Zeithaml et al., 2009).

Time. There is evidence suggesting that time affects the level of satisfaction from the purchase. Satisfaction with material purchases is more likely 
to lessen over time, for instance, when some material articles deteriorate and therefore might become less of a source of happiness (Carter \& Gilovich, 2010; Van Boven \& Gilovich, 2003). In contrast, satisfaction gained from experiential purchases tends to increase over time and might become even more positive as it is embellished in memory (Mitchell, Thompson, Peterson, \& Cronk, 1997). Research has also suggested that positive experiences remain more positive over time as they live on in memory and lend themselves to positive reinterpretations over time with negative aspects fading (Mitchell et al., 1997; Van Boven, 2005; Van Boven \& Gilovich, 2003).

To conclude, so far previous studies indicate that the level of the satisfaction derived from material purchases in comparison to the level of satisfaction derived from experiential purchases is lower due to the nature of the consumption, the tangibility of the possessions, the influence of time, the decisionmaking process, as well as the social context. However, as mentioned, the comparative studies between the two categories of purchases dealt with all the experiential purchases as one group, ignoring the differences between travel and nontravel experiential purchases while these differences could impact the individual's satisfaction from the purchases.

\section{"Travel" and "Nontravel" Purchases}

In its essence, travel experiential purchases are different from other experiential purchases in several aspects. First, the travel experience is composed of several events or encounters while the nontravel experience is a single event experience. Second, the travel experience as opposed to the nontravel experience is composed of several phases. Third, the travel experience as compared to the nontravel experience is more likely to occur while away from home, in a social context.

The first aspect of the differences between the two categories is one activity versus a series of activities. Nontravel purchases are composed of one event (e.g., attending a concert, spa treatment or dinning in a restaurant). This event takes place in the consumer's usual environment while the travel experience involves a series of activities and purchases that the travelers engage in away from home (Dolnicar et al., 2012). Tourism activities or events occur while traveling from home to destination, at the destination, and while returning home and they impact the traveler's overall evaluation of the experience (Kruger, 2012; Nawijn, Marchand, Veenhoven, \& Vingerhoets, 2010; Neal \& Gursoy, 2008; Smith, 1994). The activities include transportation, accommodations, food and beverage, and activities or events for the purpose of either leisure or business. These tourism services are linked as a chain and affect the total outcome of the travel experience, resulting in the tourist's satisfaction/ dissatisfaction or happiness (Filep, 2012; Koch, 2004; Nawijn, 2011).

As mentioned before, the second factor that distinguishes between the nontravel experience and the travel experience is the fact that the former occurs in one phase, while the latter is composed of five phases: planning phase, journey phase, destination phase, return journey phase, and revival/ memory phase (Filep, 2012; Filep \& Deery, 2010; Kruger, 2012; Nawijn et al., 2010; Neal \& Gursoy, 2008; Smith, 1994). The planning phase includes making decisions about the destination, the mode of transport, the route, and the type of accommodation. This phase may be just as enjoyable as the trip itself (Robinson, 1976). The journey phase takes the tourist beyond his home and work environment. Sometimes "getting there is half the fun" (Murphy, 1985). The destination phase represents the objective of the trip and includes the consumption of all the tourist services and activities offered at the destination. It is usually regarded the highlight of the trip (Kruger, 2012). The return journey phase refers to the tourist's psychological state and attitude induced by the prospect of returning to the everyday routine of life. The previous excitement levels decrease and the tourist may even feel tired, apathetic, and even resentful (Kruger, 2012). The revival/memory phase is the recalling of the trip experience at home. It could have either a positive or a negative effect on the tourist (Kruger, 2012).

Travelers' overall satisfaction with travel and tourism services is a function of their satisfaction with the experience in each phase of the travel (Neal \& Gursoy, 2008). Moreover, each phase by itself can lead to satisfaction, joy, and happiness (Kruger, 2012). For example, the process of preparing for a vacation (e.g., reading guidebooks) and imagining the experiences may contribute to the consumers' pleasure and happiness even more than 
experiencing the planed vacation (Aaker, Rudd, \& Mogilner, 2011). This explanation relies on findings in the field of neuroscience that have shown that the part of the brain responsible for feeling pleasure, the mesolimbic dopamine system, can be activated when merely thinking about something pleasurable (Erk, Spitzer, Wunderlich, Galley, \& Walter, 2002; McClure et al., 2004). Moreover, the brain sometimes enjoys anticipating a reward more than receiving the reward (Berns, McClure, Pagnoni, \& Montague, 2001; Loewenstein, 1987). Another example is concerning the travel phase. The last factor that distinguishes between the two experiential purchases is the social context. Most of the travel experiences are likely to be shared with others, which is not always the case in nontravel experiences (Caprariello \& Reis, 2013).

\section{Hypotheses}

Based on the literature reviewed in the previous section we hypothesize that experiential purchases are more satisfactory than material purchases. We also hypothesize that travel purchases are more satisfactory than nontravel experiential purchases. Our rationale behind this hypothesis is that while most nontravel experiential purchases consist of a single short-lived experience, a trip to a domestic or international destination is composed of a series of experiences over a longer period of time and likely to be experienced in a social context. All these characteristics make the travel experience more powerful and satisfactory. Thus, it is reasonable to suggest the existence of a rank order between the three types of purchases where travel experiences are the most satisfactory, followed by nontravel experiential purchases, with the material purchases being the least satisfactory.

More specifically we hypothesize the following:

H1a: Travel experiences lead to more satisfaction than material purchases, regardless of the expenditure amount.

H1b: Nontravel experiential purchases lead to more satisfaction than material purchases, regardless of the expenditure amount.

H1c: Travel experiences lead to more satisfaction than nontravel experiential purchases, regardless of the expenditure amount.
Since the examination of the subject is exploratory, comparison between different consumer segments can increase the validity of the study. Thus, we set up to examine the effect of nationality (as a market segment) on the levels of satisfaction with the three types of purchases. This was achieved by comparing the level of satisfaction of American and Israeli consumers with the three types of purchases: material, travel, and nontravel. These two groups differed on geographic, ethnic, cultural, economic, and religious dimensions (Katz-Gerro, 2002; Preble \& Reichel, 1988). Previous studies of the two nations found differences as well as similarities in various constructs, such as voluntary participation (Freidmann, Florin, Wandersman \& Meier, 1988) and attitude toward business ethics (Preble \& Reichel, 1988).

Due to the fact that the American and Israeli consumer purchase satisfaction hasn't been examined so far, the current study was conducted with no preformulated specific hypotheses. The intent was to discover whether there are any significant differences between the American and Israeli consumers in the satisfaction level derived from the three purchase categories.

\section{Methodology}

\section{Instruments}

To address the research questions, a survey design with questionnaire was utilized. Since the objective was to analyze the comparative levels of satisfaction of actual purchases that a respondent made in the past, we utilized Qualtrics online software capabilities to "plat" (insert) the specified purchases of each respondent into his/her questionnaire and compare them to each other. The definitions of the three categories of purchases were provided to the participants in order to ensure their understanding of each category while responding to the survey. Each respondent was requested to recall three most satisfactory purchases over the years in each of the three categories (travel, nontravel, and material).

\section{The Questionnaire}

The questionnaire consisted of four parts. In part one, respondents were asked to list in rank order 
their top three satisfactory travel experiences purchased in the past, for example: (i) a beach vacation, (ii) a ski trip, (iii) an ocean cruise. Following the same instructions, respondents were asked to list in rank order the top three satisfactory nontravel and nonmaterial experiential purchases acquired in the past, for example: (i) a spa visit, (ii) a dinner in a restaurant, (iii) a theater performance. Last, respondents were asked to list in rank order the top three satisfactory material purchases undertaken in the past, for example: (i) an item of clothing, (ii) a laptop computer, (iii) jewelry. The definition of tourism by UNWTO was inserted into the questionnaire to ensure that the participants understood the differences between travel and nontravel purchases.

In the second part, respondents were instructed to compare the three purchases in each category against each of the three purchases in the other two categories. Thus, each respondent made 27 paired comparisons between all three travel experiences, three nontravel experiential purchases, and three material purchases. For each compared pair the respondent was instructed to choose the purchase that was the most satisfactory. The use of the logistic of piping text function in Qualtrics software enabled each respondent to see and compare his chosen purchases. The selected purchase (the most satisfactory in the pair) was then assigned in the data analysis a value of 1 .

In the third part, participants were asked to list the amount of money they had paid for each of the nine purchases. The last part included demographic information.

\section{The Sample}

The questionnaire was administered to undergraduate students for two reasons: (a) students as young adults are legitimate consumers who purchased in the past products in each of the three categories and (b) the study was exploratory by nature and thus using students as subjects is permissible and appropriate for the purpose of examining the research questions.

Following Carter and Gilovich's (2010) study, conducting the research with college students is deemed appropriate when the research is exploratory in nature. The questionnaire was administered to undergraduate students at universities in
Orlando, Florida and Beer-Sheva, Israel. To collect the data from the students of both countries, the study instrument was composed in two languages: English and Hebrew. The questionnaires were cross-translated among scholars and pilot tested. Thus, the face validity was ensured.

The subjects received an invitation to participate in the study through a personal e-mail. Those who agreed to participate in the study accessed the questionnaires through a Qualtrics website. This resulted in a total of 282 respondents of which 152 studied in Orlando, Florida and 130 studied in Beer-Sheva, Israel

\section{Analyses}

The analyses included the following steps:

1. Computing the scores of each purchase category regarding satisfactory judgment. This was done by summing the number of times in which each category was preferred over another in each of the 27 paired comparisons (as described in the questionnaire section). The range of purchase satisfaction scores for each of the three purchase categories was 0 to 27 .

2. Testing hypotheses $\mathrm{H} 1 \mathrm{a}-\mathrm{H} 1 \mathrm{c}$ to determine whether there is a rank order between the three categories of purchases.

3. Analyzing the differences in the satisfaction of the purchase categories between the US and the Israeli samples.

\section{Results}

\section{Respondents’Sociodemographic Profile}

As can be seen from Table 1, the absolute majority of the respondents were single females with some college education and an annual household income of $\$ 30,000$ or less.

\section{Type of Purchases}

Table 2 presents the frequency distributions of the travel, nontravel, and material purchases that were listed by the American and Israeli respondents as the three top purchases for comparison. As can be seen from these tables, the majority of travel 
Table 1

Frequency Distribution of Respondents’

Sociodemographics

\begin{tabular}{lrrr}
\hline Variable & US & Israel & Total \\
\hline Gender & & & \\
$\quad$ Female & $76.9 \%$ & $74.4 \%$ & $75.8 \%$ \\
$\quad$ Male & $23.1 \%$ & $25.6 \%$ & $24.2 \%$ \\
Marital status & & & \\
$\quad$ Single & $86.7 \%$ & $86.8 \%$ & $86.7 \%$ \\
$\quad$ Single with children & $2.0 \%$ & $0.8 \%$ & $1.4 \%$ \\
$\quad$ Married without children & $2.7 \%$ & $3.1 \%$ & $2.9 \%$ \\
$\quad$ Married with children & $8.0 \%$ & $6.2 \%$ & $7.2 \%$ \\
$\quad$ Other & $0.6 \%$ & $3.1 \%$ & $1.8 \%$ \\
Education & & & \\
$\quad$ High school & $4.1 \%$ & $0.8 \%$ & $2.5 \%$ \\
$\quad$ Some college & $85.2 \%$ & $95.3 \%$ & $89.9 \%$ \\
$\quad$ Graduate degree & $10.7 \%$ & $3.9 \%$ & $7.6 \%$ \\
Annual household income & & & \\
$\quad$ \$30,000 or less & $54.4 \%$ & $81.4 \%$ & $66.9 \%$ \\
$\quad$ \$30,001-\$50,000 & $14.1 \%$ & $10.1 \%$ & $12.2 \%$ \\
$\quad$ \$50,001-\$70,000 & $6.7 \%$ & $2.3 \%$ & $4.7 \%$ \\
$\quad$ \$70,001-\$100,000 & $9.4 \%$ & $2.3 \%$ & $6.1 \%$ \\
Over \$100,000 & $15.4 \%$ & $3.9 \%$ & $10.1 \%$ \\
\hline
\end{tabular}

purchases were to domestic destinations while the bulk of the nontravel experiential purchases were in the categories of parties and performance shows. As far as material purchases, the three major types of purchase for American respondents were clothing and footwear, electronic devices, and accessories, while the top two categories of material purchases for Israeli respondents were electronic devices and clothing and footwear.

\section{Satisfaction With the Purchases}

As can be seen from Table 3, of the three types of purchases, the most satisfactory was travel experiences (mean $=12.17$ ) followed by nontravel experiential purchases (mean $=7.43$ ), with the least satisfactory being the material purchases ( mean $=7.40$ ).

Table 3 also presents the paired $t$-test results of these satisfaction scores and shows that travel experiences were more satisfactory than both nontravel experiential purchases (H1c is confirmed) and material purchases (H1a is confirmed). However, the results only partially support the rank order hypothesis as the difference between the satisfactory scores of nontravel experiential purchases and material purchases was not statistically significant, thus H1b was not confirmed.

\section{Amount Spent on Purchases}

The average amounts spent by respondents on purchases were: \$2,541 for material purchases, \$533 for travel purchases, and \$218 for nontravel experiential purchases. To test whether satisfaction was related to the amount paid within each of the expenditure categories, a series of correlations between satisfaction and each of the expenditure categories for both samples was conducted. Satisfaction with the travel purchases was not related to the amount spent for either American or Israeli samples. The same was true for satisfaction with nontravel experiential purchases. However, in the case of material purchases for the US sample, satisfaction with material purchases was significantly correlated $(r=$ $0.21, p=0.029$ ) to the amount paid. The higher the amount paid, the more satisfied American respondents were with their material purchases.

\section{Satisfaction: A Cross-National Comparison}

To examine whether differences in mean satisfaction scores of the purchases between the two sample groups exist, $t$-tests were conducted. As can be seen in Table 4, American respondents were more satisfied with their travel experiences than their Israeli counterparts, while Israelis were more satisfied with material purchases. However, there were no significant differences identified in nontravel satisfaction purchases.

Regarding the comparison between two nations, the rank orders of the three categories were found to be similar. Both American and Israelis samples show the same order as travel purchase satisfaction is higher than both nontravel and material purchases. No differences were found between nontravel and material purchase satisfaction (Table 5).

\section{Discussion and Conclusions}

Building upon previous studies which indicated that consumers achieved higher levels of satisfaction and happiness resulting from experiential purchases than material purchases (Caprariello \& Reis, 2013; Dunn et al., 2011; Goodman \& Lim, 2015; Howell \& Hill, 2009; Nicolao et al., 2009; Van Boven \& Gilovich, 2003), this study aimed to further examine if this phenomenon: (a) holds across nations, (b) is 
Table 2

Frequency Distribution of Travel, Nontravel Experiential, and Material Purchases

\begin{tabular}{|c|c|c|c|c|c|c|c|c|}
\hline & \multicolumn{2}{|c|}{ Purchase No.1 } & \multicolumn{2}{|c|}{ Purchase No. 2} & \multicolumn{2}{|c|}{ Purchase No. 3} & \multicolumn{2}{|c|}{ Mean } \\
\hline & US & Israel & US & Israel & US & Israel & US & Israel \\
\hline \multicolumn{9}{|l|}{ Travel experiential purchases } \\
\hline Domestic destinations & $54 \%$ & $86 \%$ & $77 \%$ & $96 \%$ & $80 \%$ & $97 \%$ & $70.3 \%$ & $93.0 \%$ \\
\hline International destinations & $30 \%$ & $11 \%$ & $10 \%$ & $3 \%$ & $15 \%$ & $1 \%$ & $18.3 \%$ & $5.0 \%$ \\
\hline Cruises & $16 \%$ & $0 \%$ & $11 \%$ & $0 \%$ & $5 \%$ & $1 \%$ & $10.7 \%$ & $0.3 \%$ \\
\hline Special tours ${ }^{\mathrm{a}}$ & $0 \%$ & $3 \%$ & $2 \%$ & $1 \%$ & $0 \%$ & $1 \%$ & $0.7 \%$ & $1.7 \%$ \\
\hline Total & $100 \%$ & $100 \%$ & $100 \%$ & $100 \%$ & $100 \%$ & $100 \%$ & $100 \%$ & $100 \%$ \\
\hline \multicolumn{9}{|c|}{ Nontravel experiential purchases } \\
\hline Parties ${ }^{b}$ & $52 \%$ & $8 \%$ & $20 \%$ & $22 \%$ & $22 \%$ & $6 \%$ & $31.3 \%$ & $12.0 \%$ \\
\hline Shows ${ }^{\mathrm{c}}$ & $14 \%$ & $58 \%$ & $25 \%$ & $32 \%$ & $28 \%$ & $45 \%$ & $22.3 \%$ & $45.0 \%$ \\
\hline Dinner at a restaurant $\mathrm{d}^{\mathrm{d}}$ & $8 \%$ & $6 \%$ & $12 \%$ & $18 \%$ & $20 \%$ & $24 \%$ & $13.3 \%$ & $16.0 \%$ \\
\hline Leisure activities $^{\mathrm{e}}$ & $14 \%$ & $12 \%$ & $18 \%$ & $11 \%$ & $17 \%$ & $20 \%$ & $16.3 \%$ & $14.3 \%$ \\
\hline $\mathrm{Spa}^{\mathrm{f}}$ & $12 \%$ & $16 \%$ & $21 \%$ & $17 \%$ & $12 \%$ & $5 \%$ & $15.0 \%$ & $12.7 \%$ \\
\hline Beauty treatment & $0 \%$ & $0 \%$ & $4 \%$ & $0 \%$ & $1 \%$ & $0 \%$ & $1.7 \%$ & $0 \%$ \\
\hline Total & $100 \%$ & $100 \%$ & $100 \%$ & $100 \%$ & $100 \%$ & $100 \%$ & $100 \%$ & $100 \%$ \\
\hline \multicolumn{9}{|l|}{ Material purchases } \\
\hline Clothing and footwear & $23 \%$ & $17 \%$ & $29 \%$ & $30 \%$ & $26 \%$ & $26 \%$ & $26.0 \%$ & $24.3 \%$ \\
\hline Accessories ${ }^{g}$ & $28 \%$ & $0 \%$ & $19 \%$ & $4 \%$ & $15 \%$ & $6 \%$ & $20.7 \%$ & $3.3 \%$ \\
\hline Jewelry & $8 \%$ & $9 \%$ & $9 \%$ & $10 \%$ & $9 \%$ & $9 \%$ & $8.7 \%$ & $9.3 \%$ \\
\hline Electronic devices ${ }^{\mathrm{h}}$ & $25 \%$ & $64 \%$ & $27 \%$ & $41 \%$ & $25 \%$ & $33 \%$ & $25.7 \%$ & $46.0 \%$ \\
\hline Leisure activities products ${ }^{\mathrm{i}}$ & $2 \%$ & $3 \%$ & $3 \%$ & $6 \%$ & $7 \%$ & $6 \%$ & $4.0 \%$ & $5.0 \%$ \\
\hline Transportation vehicles ${ }^{\mathrm{j}}$ & $6 \%$ & $5 \%$ & $9 \%$ & $2 \%$ & $3 \%$ & $3 \%$ & $6.0 \%$ & $3.3 \%$ \\
\hline Furniture & $2 \%$ & $2 \%$ & $2 \%$ & $2 \%$ & $10 \%$ & $9 \%$ & $4.7 \%$ & $4.3 \%$ \\
\hline Household equipment $\mathrm{t}^{\mathrm{k}}$ & $2 \%$ & $0 \%$ & $0 \%$ & $2 \%$ & $1 \%$ & $2 \%$ & $1.0 \%$ & $1.3 \%$ \\
\hline Art works ${ }^{1}$ & $0 \%$ & $0 \%$ & $1 \%$ & $0 \%$ & $1 \%$ & $2 \%$ & $0.7 \%$ & $0.7 \%$ \\
\hline Cosmetics & $4 \%$ & $0 \%$ & $1 \%$ & $3 \%$ & $3 \%$ & $4 \%$ & $2.7 \%$ & $2.3 \%$ \\
\hline Total & $100 \%$ & $100 \%$ & $100 \%$ & $100 \%$ & $100 \%$ & $100 \%$ & $100 \%$ & $100 \%$ \\
\hline
\end{tabular}

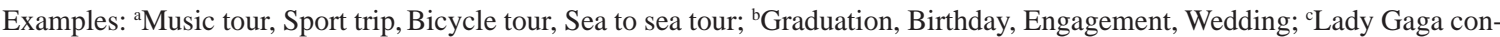
cert, Cirque du Soleil show, Theater, Madonna concert, Music festival; ${ }^{\mathrm{S}}$ Special occasion dinner at a restaurant; ${ }^{\mathrm{e}}$ Fishing, Shopping, Fitness club membership, Skydiving, Diving, Rock climbing; ${ }^{\mathrm{f}}$ Massage, Reflexology; ${ }^{\mathrm{g}}$ Handbags, Watches, Sunglasses; ${ }^{h}$ Laptop computers, iPads, Smartphones, Sony Play stations, TVs, Cameras; ${ }^{i}$ Tennis rackets, Fishing gear, Musical instruments, Diving equipment, Toys, Music CDs; ${ }^{j}$ Bicycles, Cars, Motorcycles; ${ }^{k}$ Coffee makers, Mixers, Minirefrigerators, Vacuum cleaners, Refrigerators; ${ }^{1}$ Examples: Paintings, Photographs.

Table 3

Satisfaction With Travel Experience, Nontravel Experience, and Material Purchases: Paired $t$-Test Results

\begin{tabular}{lrrrccc}
\hline & Mean & $N$ & SD & $t$-Test & $d f$ & $\begin{array}{c}\text { Sig. } \\
\text { (Two-Tailed) }\end{array}$ \\
\hline Pair 1 & & & & 12.38 & 281 & 0.000 \\
$\quad$ Travel & 12.17 & 282 & 4.03 & & & \\
$\quad$ Nontravel & 7.43 & 282 & 3.76 & & & \\
Pair 2 & & & & 10.54 & 281 & 0.000 \\
$\quad$ Travel & 12.17 & 282 & 4.03 & & & \\
$\quad$ Material & 7.40 & 282 & 4.42 & & & \\
Pair 3 & & & & 0.06 & 281 & 0.954 \\
$\quad$ Nontravel & 7.43 & 282 & 3.76 & & & \\
$\quad$ Material & 7.40 & 282 & 4.42 & & & \\
\hline
\end{tabular}

Table 4

Satisfaction Cross-National Comparison: $t$-Tests Results

Sig.

\begin{tabular}{lcccccc} 
Sample & $N$ & Mean & SD & $t$ & $d f$ & (Two-Tailed) \\
\hline $\begin{array}{l}\text { Travel } \\
\quad \text { US }\end{array}$ & 152 & 13.26 & 4.03 & & & \\
$\quad$ Israel & 130 & 10.89 & 3.67 & & & \\
$\begin{array}{c}\text { Nontravel } \\
\quad \text { US }\end{array}$ & 152 & 7.36 & 3.85 & & & \\
$\quad$ Israel & 130 & 7.52 & 3.66 & & & \\
Material & & & & -4.30 & 280 & 0.00 \\
$\quad$ US & 152 & 6.40 & 4.17 & & & \\
$\quad$ Israel & 130 & 8.59 & 4.43 & & & \\
\hline
\end{tabular}


Table 5

Satisfaction With Travel Experience, Nontravel Experience, and Material Purchases: Cross-Cultural Comparison

\begin{tabular}{|c|c|c|c|c|c|c|}
\hline & Mean & $N$ & SD & $t$-Test & $d f$ & $\begin{array}{c}\text { Sig. } \\
\text { (Two-Tailed) }\end{array}$ \\
\hline \multicolumn{7}{|l|}{ US sample } \\
\hline Pair 1 & & & & 10.87 & 151 & 0.00 \\
\hline Travel & 13.26 & 152 & 4.03 & & & \\
\hline Nontravel & 7.36 & 152 & 3.85 & & & \\
\hline Pair 2 & & & & 11.69 & 151 & 0.00 \\
\hline Travel & 13.26 & 152 & 4.03 & & & \\
\hline Material & 6.39 & 152 & 4.17 & & & \\
\hline Pair 3 & & & & 1.71 & 151 & 0.09 \\
\hline Nontravel & 7.36 & 152 & 3.85 & & & \\
\hline Material & 6.39 & 152 & 4.17 & & & \\
\hline \multicolumn{7}{|l|}{ Israel sample } \\
\hline Pair 1 & & & & 6.59 & 129 & 0.00 \\
\hline Travel & 10.89 & 130 & 3.67 & & & \\
\hline Nontravel & 7.52 & 130 & 3.66 & & & \\
\hline Pair 2 & & & & 3.61 & 129 & 0.00 \\
\hline Travel & 10.89 & 130 & 3.67 & & & \\
\hline Material & 8.59 & 130 & 4.43 & & & \\
\hline Pair 3 & & & & -1.69 & 129 & 0.09 \\
\hline Nontravel & 7.52 & 130 & 3.66 & & & \\
\hline Material & 8.59 & 130 & 4.44 & & & \\
\hline
\end{tabular}

affected by the amount of money spent on the purchases, and (c) whether there is a difference in the level of satisfaction between travel and nontravel experiential purchases. Three purchase satisfaction categories were analyzed: (1) travel, (2) nontravel, and (3) material. In addition, the amount of money spent was included in the analysis, along with results from a cross-national comparison. The study revealed that satisfaction resulting from travel purchases is significantly higher than satisfaction derived from nontravel experiential purchases and material purchases. However, no difference was found between satisfaction levels resulting from nontravel versus material purchases. The findings of the study partially confirmed previous studies contending that experiential purchases are more satisfactory than material purchases (Caprariello \& Reis, 2013; Carter \& Gilovich, 2010; Van Boven \& Gilovich, 2003). Moreover, these findings provide additional insight into the role travel and tourism activities have on satisfaction and happiness as implied by Filep and Deery, (2010); Neal, Sirgy, and Uysal (1999); Neal et al., (2007), and Sirgy, Kruger, Lee, and Grace (2011). The current study found that travel was the only component of experiential purchases that was significantly more satisfactory than material purchases, while no significant differences between nontravel experiences and material purchases were noted. Moreover, this study found within the experiential purchase satisfaction comparison that satisfaction resulting from travel purchases is significantly higher than satisfaction derived from nontravel experiential purchases. This finding is congruent with the finding of Dolnicar et al. (2012), who identified the disparity between the contribution of leisure activities and vacations to one's quality of life (QOL). Furthermore, this finding provides new insight into the material experience satisfaction line of research. Previous studies (Caprariello \& Reis, 2013; Carter \& Gilovich, 2010; Nicolao et al., 2009; Van Boven \& Gilovich, 2003) that compared and contrasted experiential purchases to material purchases viewed experiential purchases as one category, ignoring the two subcategories of travel ("vacations," "travel”) and nontravel ("concerts," "sporting events," "dining”). The results of the study suggest that the differences in the level of satisfaction derived from the experiential and the material purchases mentioned earlier were due to the contribution of travel experience and might even be mitigated due to the interfering effect of the nontravel experiences.

Furthermore, in order to deepen the understanding of how purchase categories influence the individual's satisfaction, nationality differences were also examined. This was done by comparing differences between American and Israeli respondents. In the two subsamples, travel purchases provided a higher satisfaction than nontravel purchases and material purchases. However, the differences in the satisfaction derived from nontravel purchases and material purchases were not found to be statistically significant in either the American or Israeli subsamples. These findings show that, on the one hand, travel experiences are more satisfactory than material purchases, yet, on the other hand, there are no differences in the satisfaction derived from nontravel experiences and material purchases. The findings partially support previous studies (Carter \& Gilovich, 2010; Van Boven \& Gilovich; 2003). Our explanation to this discrepancy is based on the difference in conceptualization of the experiential purchases. As noted earlier, there are differences in the nature of these two categories of experiential purchases. These differences might result in differences in the consumer's 
satisfaction, happiness, and well-being. The findings of the current study support this approach.

To determine whether satisfaction was impacted by the expenditure level, an additional analysis was performed. Although price was found in some studies to moderate the relationships between consumption and satisfaction (Voss, Parasuraman, \&Grewal 1998; Ryu \& Han, 2010), our study revealed conflicting results. That is, no significant correlation was found to exist between the amount of money spent and the purchase satisfaction in either travel or nontravel experiential categories. This was true for both American and Israeli samples. However, this was not the case for material purchases. Satisfaction was positively correlated to the amount spent only in the American sample. Of the three categories, the average amount spent was highest for material purchases, followed by travel, with nontravel expenditures the lowest. As the analysis revealed that satisfaction derived from travel purchases was the highest, these findings imply that the amount of money paid does not assure satisfaction.

However, this study went beyond previous comparison studies of experiential and material purchases and proved that travel purchases-which belong in the realm of experiential purchaseswere more satisfactory than nontravel experiential purchases. Despite the fact that respondents paid the most for material purchases, these were less satisfactory than travel experiential purchases. Thus, it is possible to partially confirm the existence of a rank order of satisfaction between the three types of purchases in the following order: travel experiences the most satisfactory, followed by nontravel experiential and material purchases.

\section{Study Limitations and Future Research}

The major contribution of this study was the discovery of the significance of travel purchase satisfaction compared to material and nontravel purchase satisfaction. The findings of the study also suggest that price is not a determinant of satisfaction. However, since more costly material purchases resulted in higher satisfaction than nontravel purchase satisfaction, future research should further examine this phenomenon as well as other factors related to postpurchases of material and experiential products and services (e.g., memorability, gift giving, etc.).
The study was exploratory in nature, comparing three categories of purchase satisfaction. The participants were young adults who were college students with work experience and earned income. Because the sample was composed of students at state-owned universities, it may have resulted in a limited range of actual purchases used for comparison purposes. We recommend that future studies should duplicate this study with other consumer segments. In addition, exploring the differences among specific purchases in travel and nontravel purchases will provide more insight to this line of research.

Since this study was conducted in US and Israel, generalization of the findings to broader populations is limited. Therefore, studies focusing on crosscultural comparisons of other countries are also suggested. Finally, as this research examined only purchases that were deemed satisfying, it would also be interesting to investigate unsatisfactory purchases to determine if symmetry also exists in the rank order and relationships found in this study.

\section{References}

Aaker, J. L., Rudd, M., \& Mogilner, C. (2011). If money does not make you happy, consider time. Journal of consumer psychology, 21(2), 126-130.

Argyle, M. (1999). Causes and correlates of happiness. In D. Kahneman, E. Diener, \& N. Schwarz (Eds.), Well-being: The foundations of hedonic psychology (pp. 353-373). New York: Russell Sage Foundation.

Baumeister, R. F., \& Leary, M. R. (1995). The need to belong: desire for interpersonal attachments as a fundamental human motivation. Psychological Bulletin, 117(3), 497-529.

Berns, G. S., McClure, S. M., Pagnoni, G., \& Montague, P. R. (2001). Predictability modulates human brain response to reward. Journal of Neuroscience, 21, 2793-2798.

Caprariello, P. A., \& Reis, H. T. (2013). To do, to have, or to share? Valuing experiences over material possessions depends on the involvement of others. Journal of Personality and Social Psychology, 104(2), 199-215.

Carter, T. J., \& Gilovich, T. (2010). The relative relativity of material and experiential purchases. Journal of Personality and Social Psychology, 98(1), 146-159.

Carter, T. J., \& Gilovich, T. (2012). I am what I do, not what I have: The differential centrality of experiential and material purchases to the self. Journal of Personality and Social Psychology, 102(6), 1304-1317.

Dolnicar, S., Yanamandram, V., \& Cliff, K. (2012). The contribution of vacations to quality of life. Annals of Tourism Research, 39(1), 59-83.

Dunn, E. W., Gilbert, D. T., \& Wilson, T. D. (2011). If money doesn't make you happy, then you probably aren’t spending it right. Journal of Consumer Psychology, 21(2), 115-125. 
Erk, S., Spitzer, M., Wunderlich, A. P., Galley, L., \& Walter, H. (2002). Cultural objects modulate reward circuitry. Neuroreport, 13(18), 2499-2503.

Filep, S. (2012). Moving beyond subjective well-being: A tourism critique. Journal of Hospitality \& Tourism Research, 38(2), 266-274.

Filep, S., \& Deery, M. (2010). Towards a picture of tourists' happiness. Tourism Analysis, 15(4), 399-410.

Friedmann, R. R., Florin, P., Wandersman, A., \& Meier, R. (1988). Local action on behalf of local collectives in the US and Israel: How different are leaders from members in voluntary associations? Nonprofit and Voluntary Sector Quarterly, 17(3-4), 36-54.

Goodman, J. K., \& Lim, S. (2015). Giving happiness: Consumers should give more experiences but choose material gifts instead (working paper). Retrieved from http://apps. olin.wustl.edu/faculty/goodman/Giving\%20Happiness.pdf

Howell, R. T., \& Hill, G. (2009). The mediators of experiential purchases: Determining the impact of psychological needs satisfaction and social comparison. The Journal of Positive Psychology, 4(6), 511-522.

Katz-Gerro, T. (2002). Highbrow cultural consumption and class distinction in Italy, Israel, West Germany, Sweden, and the United States. Social Forces, 81(1), 207-229.

Koch, K. (2004). Quality of offensive in Swiss tourism. Berne: State Secretarial for Economic Affairs.

Kruger, P. S. S. (2012). Perceptions of tourism impacts and satisfaction with particular life domains. In Handbook of tourism and quality-of-life research (pp. 279-292). Netherlands: Springer.

Loewenstein, G. (1987). Anticipation and the valuation of delayed consumption. The Economic Journal, 97, 666-684.

McClure, S. M., Li, J., Tomlin, D., Cypert, K. S., Montague, L. M., \& Montague, P. R. (2004). Neural correlates of behavioral preference for culturally familiar drinks. Neuron, 44(2), 379-387.

Mitchell, T. R., Thompson, L., Peterson, E., \& Cronk, R. (1997). Temporal adjustments in the evaluation of events: The "rosy view." Journal of Experimental Social Psychology, 33, 421-448.

Murphy, P. E. (1985). Tourism: A community approach. New York: Methuen.

Nawijn, J. (2011). Determinants of daily happiness on vacation. Journal of Travel Research, 50(5), 559-566.

Nawijn, J., Marchand, M. A., Veenhoven, R., \& Vingerhoets, A. J. (2010). Vacationers happier, but most not happier after a holiday. Applied Research in Quality of Life, 5(1), 35-47.

Neal, J. D., \& Gursoy, D. (2008). A multifaceted analysis of tourism satisfaction. Journal of Travel Research, 47(1), 53-62.

Neal, J. D., Sirgy, M. J., \& Uysal, M. (1999). The role of satisfaction with leisure travel/tourism services and experience in satisfaction with leisure life and overall life. Journal of Business Research, 44(3), 153-163.

Neal, J. D., Uysal, M. J., \& Sirgy, J. (2007). The effect of tourism services on travelers' quality of life. Journal of Travel Research, 46, 154-163.
Nicolao, L., Irawin, J. R., \& Goodman J. K. (2009). Happiness for sale: Do experiential purchases make consumers happier than material purchases? Journal of Consumer Research, 36(2), 188-198.

Preble, J. F., \& Reichel, A. (1988). Attitudes towards business ethics of future managers in the U.S. and Israel. Journal of Business Ethics, 7, 941-949.

Raghunathan, R., \& Corfman, K. (2006). Is happiness shared doubled and sadness shared halved? Social influence on enjoyment of hedonic experiences. Journal of Marketing Research, 43(3), 386-394.

Reis, H. T., Smith, S. M., Carmichael, C. L., Caprariello, P. A., Tsai, F. F., Rodrigues, A., \& Maniaci, M. R. (2010). Are you happy for me? How sharing positive events with others provides personal and interpersonal benefits. Journal of Personality and Social Psychology, 99, 311-329.

Robinson, H. (1976). A geography of tourism. London: Macdonald \& Evans.

Rosenzweig, E., \& Gilovich, T. (2012). Buyer's remorse or missed opportunity? Differential regrets for material and experiential purchases. Journal of Personality and Social Psychology, 102(2), 215-223.

Ryan, R. M., \& Deci, E. L. (2000). Intrinsic and extrinsic motivations: Classic definitions and new directions. Contemporary Educational Psychology, 25, 54-67.

Ryu, K., \& Han, H. (2010). Influence of the quality of food, service, and physical environment on customer satisfaction and behavioral intention in quick-casual restaurants: Moderating role of perceived price. Journal of Hospitality \& Tourism Research, 34(3), 310-329.

Sirgy, M. J., Kruger, P. S., Lee, D. J., \& Grace, B. Y. (2011). How does a travel trip affect tourists' life satisfaction? Journal of Travel Research, 50(3), 261-275.

Smith, S. J. (1994). The tourism product. Annals of Tourism Research, 21(3), 582-595.

Van Boven, L. (2005). Experientialism, materialism, and the pursuit of happiness. Review of General Psychology, 9(2), 132-142.

Van Boven, L. Campbell, M. C., \& Gilovich, T. (2010). Stigmatizing materialism: On stereotypes and impressions of materialistic and experiential pursuits. Personality and Social Psychology Bulletin, 36(4), 551-563.

Van Boven, L., \& Gilovich, T. (2003). To do or to have? That is the question. Journal of Personality and Social Psychology, 85, 1193-1202.

Voss, G. B., Parasuraman, A., \& Grewal, D. (1998). The roles of price, performance, and expectations in determining satisfaction in service exchanges. The Journal of Marketing, 62(4), 46-61.

Zeithaml, V. A., Bitner, M. J., \& Gremler, D. D. (2009). Services marketing-Integrating customer focus across the firm. New York: McGraw-Hill. 